DOI https://doi.org/10.36059/978-966-397-154-4/185-200

\title{
PECULIARITIES OF THE IMPLEMENTATION OF THE BASIN PRINCIPLE IN THE MANAGEMENT OF WATER RESOURCES IN UKRAINE
}

\section{Stashuk V. A.}

\section{INTRODUCTION}

The water resources of Ukraine are the part of natural water reserves that are directly involved or may be involved in social production under specific historical conditions with a certain development of productive forces. This definition characterizes water resources not only as a natural phenomenon, but also as a socioeconomic category that is directly connected with the level of the development of society. Owing to the specific features, which differentiate them from other natural resources (high dynamism and interconnections, which is explained by the objective processes of water circulation in nature), water resources could be used many times and for different purposes that requires optimization of water use.

The water resources of our planet are about 1.5 billion cubic $\mathrm{km}$. However, $98 \%$ of them are saline waters of the World Ocean, and only 28 million cubic $\mathrm{km}$ are fresh-waters. But owing to the technological possibilities for desalination of saline sea-waters, the waters of the oceans and saline lakes could be considered as potential water resources, the use of which is quite possible in the future.

The river runoff resources of Ukraine average to 87 billion cubic $\mathrm{m}$ per year (in low water year this index decreases to 56 billion cubic $\mathrm{m}$ ). The river network of Ukraine is more than 71,000 rivers with the total length of more than 170 thousand $\mathrm{km}$. Its average density is $0.25 \mathrm{~km} / \mathrm{km} 2$. Almost all rivers belong to the basins of the Black and Azov seas and only $4 \%$ belong to the Baltic Sea. Water resources of Ukraine are formed mainly owing to the runoff of the Dnipro, Dnister, Siverskyi Donets, Pivdennyi Buh, Tysa rivers, on which the reservoirs are built. Specific supply of the river runoff in Ukraine - about 1 thousand cubic $\mathrm{m}$ per person per year that is 2.5 times 
lower than in Germany and Sweden, 3.5 times than in France and 5 times than in England ${ }^{1}$.

Ukraine belongs to the least supplied with own water resources country of Europe. Most natural water sources are scarce, and water resources of Ukraine become a limiting factor in the development and allocation of productive forces. Water use volumes in the river basins have almost reached the upper limit, and there is a conflict between the demand for water and the capacity to meet it both in quantity and quality (especially for drinking purposes). Because of excessive anthropogenic load, disturbance of the conditions of the river runoff formation and natural balance, which led to a decrease in the quality of water resources, the threatening ecological condition has developed in almost all river basins of Ukraine, and especially in the Dnipro basin - the main source of water supply in the country. More than $70 \%$ of the state's water supply is provided by the surface runoff of the Dnipro basin ${ }^{2}$. Therefore, the question of rational use of water resources, their reproduction and protection is the main task of the state policy of Ukraine today.

\section{Assessment of anthropogenic load on the river basins of Ukraine}

The water economy system is a hydraulically and organizationally interconnected set of sources of water resources, water users, water management tools for their rational use, reproduction, storage and protection against pollution. Water economy system (WES) consists of a great number of elements aimed to satisfy economic, socioenvironmental, aesthetic and other needs of society in water of the required quantity and quality. Besides meeting the needs of production and society for water in the appropriate volume, regime and quality, it is also intended to maintain ecological balance in the basin and protect the environment from the harmful effects of water. The water economy system can be classified as a large (complex) system because it contains water resources as a basis, consists of many artificial engineering constructions and has branchy links with the natural, social and economic environment.

To provide consumers with water in the appropriate volumes and quality, different water economy constructions are used depending on the purpose of the water. The main constructions of water supply are water intakes, pump

\footnotetext{
1 Постанова Верховної Ради України «Про Концепцію розвитку водного господарства України». Прийняття від 14.01.2000. Режим доступу: https://zakon.rada.gov.ua/laws/show/1390-14

2 Данилишин Б. М., Дорогунцов С. І., Міщенко В. С., Коваль Я. В., Новоторов О. С., Паламарчук М. М. Природно-ресурсний потенціал сталого розвитку України. К.: РВПС України, 1999. 716 с.
} 
stations, regulating constructions, canals and water diversion systems, water purification stations and water distribution systems. Various protective constructions (flood dams, antislip structures, water drainage constructions, etc.) are used to prevent the harmful effects of water and to prevent accidents and catastrophes.

A distinctive feature of water economy systems is their inter-sector character. Water in Ukraine is used by about 30 thousand types of water users, among which are objects of national, regional and territorial and local importance, which extremely complicates the efficient management of them. Water resources management begins with planning of the regimes of the water economy system, which is based on the analysis of water economy balances. Therefore, water resources management is a complex technological process, which is carried out by organizing appropriate measures in such a way that the optimal use of available resources (water, energy, human) is provided to achieve the intended purpose - provision of all consumers with calculated reliability of water with the required volumes and quality.

The water economy complex of the Dnipro basin has been developed for several decades in the direction of increasing water use and runoff regulation without taking into account economic and environmental consequences for Ukraine. The largest number of industrial enterprises, the largest energy facilities and arrays of irrigated lands are concentrated in the Dnipro basin. Despite the fact that water uptake from the Dnipro River and the rivers of its basin has recently considerably decreased, the quality of the Dnipro water has not improved due to the loss of restorative capacity and the decrease in the efficiency of purification constructions. The Dnipro provides water to consumers not only within its basin, but is also the main source of water supply for industrial centers of the South and Southeast of Ukraine. The Dnipro-Donbas, the North Crimean, the Kakhovka canals annually transfer 5-6 billion $\mathrm{m}^{3}$ of water outside the basin. Water supply to Donbas, Kharkiv, Kryvbas, Crimea is solved by supplying the Dnipro water.

The ecological situation in the Dnipro basin is related to the processes of soil erosion due to the high level of plowed land (up to 70\% of the basin area) and low forest cover (twice less than optimal). Soil erosion products are carried away by the surface runoff and pollute rivers and reservoirs. Contamination of water, as well as water intake landscapes, with chemical compounds, has led to changes in the natural balance of many rivers of the basin, complicating the problem of obtaining qualitative drinking water due to the imperfect water purification technologies under the conditions of increasing anthropogenic and radiation loads on the environment. Much of 
the Dnipro basin and cascade reservoirs are contaminated with radionuclides. Surface and groundwater, soils of the Dnipro basin are very polluted. The level of this pollution has reached the levels at which it is impossible to clean them with the available technologies and purification facilities.

The water economy complex of Ukraine has developed over many decades without taking into account environmental requirements and environmental consequences. The self-healing capacity of the water resources of Ukraine is already insufficient to overcome the negative impacts and recover the disturbed ecological balance. Particularly unsettling is the fact that in recent years not only levels of pollution of wastewater effluents have increased, but also volumes of wastewater that are not treated at all. In the last decade, due to the aging and excessive wear of water purification constructions, their considerable energy intensity and technological backwardness and reduced efficiency, the environmental risk of mass technological and environmental accidents and catastrophes in water bodies has increased. The extreme technogenic load on the water resources of the country resulted in that all surface and connected with them groundwater are contaminated with a significant exceed of the maximum permissible concentration (MPC).

An increase in the discharge of contaminated wastewater without purification is observed in the Dnipro basin (by 72.3\%), the Crimean rivers (by 50\%) and the Southern Buh basin (by 21\%). The discharge of such waters in the Siverskyi Donets basin (by 22\%) and the Danube (by 30\%) has slightly decreased. According to the Institute of Geography of the National Academy of Sciences of Ukraine, the water quality according to the integrated ecological index (at an index of more than 12 it is water of «poor» quality) for the territory of Ukraine is characterized by the following: the most polluted water is in the Donbas, the Steppe zone of the Dnipro, in the Azov region (Donetsk index - 45.3, Dnipropetrovsk - 16.7, Zaporizhzhia 12.4; Mariupol - 31.0) $)^{3}$.

Considerable attention to solving the problems of drinking water supply and improving the ecological conditions of water sources is paid in the Law of Ukraine «National Target Program for the Development of Water Economy and Environmental Healing of the Dnipro River by $2021 »{ }^{4}$. Based on the analysis of ecological conditions and hydro-chemical composition of

\footnotetext{
${ }^{3}$ Дезірон О. В. Водокористування в Україні: сучасний стан та перспективи розвитку. Водне господарство України. К.: 2003, № 3-4. С. 4-8.

4 Закон України «Загальнодержавна цільова програма розвитку водного господарства та екологічного оздоровлення р. Дніпро до 2021 року». Прийняття від 24.05.2012. Режим доступу: https://zakon.rada.gov.ua/laws/show/4836-17
} 
water of the basins of the main rivers of Ukraine, we can draw the following conclusions:

1. The technogenic load on aquatic ecosystems has reached a critical limit due to the extensive way of management, which has led to a significant reduction in ecological and sanitation costs and the depletion of water resources.

2. There is a tendency for permanent pollution of surface waters due to the discharge of unpurified or insufficiently purified waste-waters into reservoirs, diversion of effluents from settlements and agricultural lands, unsatisfactory technical condition and level of exploitation of water economy systems and purification facilities.

3. The deterioration of surface waters quality, and especially of drinking water, because of the poor ecological conditions of water sources in the basins, the use of imperfect outdated water treatment technologies in existing water supply systems.

4. The main pollutants of the water of the Dnipro basin are biogenic elements (organic and nitrogen compounds, iron) and there is a gradual increase in water mineralization, content of ammonium nitrogen, nitrates, phosphates, heavy metals that testifies about an increase of anthropogenic load on the water objects, ineffective functioning of the purification constructions of cities and industrial enterprises and an increase in discharges of unpurified or insufficiently purified waste-waters.

5. The crisis of water economy and ecological situation in the basin of the main rivers of Ukraine is caused by the nature of farming and the discharge into the water bodies of a considerable amount of polluted waters of industry, agriculture and communal services. Particularly harmful are surfactants, pesticides, biogenic substances, heavy metals, petroleum products, phenols.

6. The great effect on the environmental conditions of rivers, including the volume of floods, has a negative change in the water intake areas of small rivers due to the soil erosion and low forest cover (deforestation).

7. The lack of an efficient economic mechanism of water management and implementation of environmental measures, the imperfection of the existing system of management of protection and use of water resources due to the lack of a legal framework have a negative effect on the solution of ecological water problems.

Thus, at the present level of anthropogenic load, almost most rivers of Ukraine have lost their ability to self-purification, and the condition of rivers, especially small ones, is approaching the limit of pollution, which can lead to dramatic disturbance of natural ecosystems. 


\section{Improvement of the state policy in water resources and water economy management}

Determination and scientific substantiation of strategic goals and directions of the increase of ecological sustainability and balanced development of water economy, provision of the population with qualitative drinking water, minimization of losses and social tension due to the harmful effect of water, conservation of aquatic ecosystems - this is not a complete list of priority tasks, solving of which is envisaged by the state programs.

The realization of the envisaged measures is based on a comprehensive assessment of the level of natural provision with water resources, peculiarities of their territorial distribution, which does not correspond to the location of water-intensive branches of the economic complex. Although gross domestic product has declined considerably in recent years, there is a tendency for an increase in the discharge of contaminated wastewater, $88 \%$ of which is attributed to the ferrous metallurgy, coal and chemical industries. The volume of pollution of municipal wastewater has increased 1.4 times $^{5}$. At the same time, the indexes are increasing every year, which indicates that with a significant reduction in production, the environmental situation in Ukraine is not improving, and the resource and water consumption of the products is increasing.

The crisis of water resources, apart from technogenic load, is caused by the fact that Ukraine is one of the least water-supplied countries in Europe. According to UNESCO, Ukraine ranks 95th among 122 countries in terms of rational use of water resources and water quality, including the availability of purification facilities.

The cause of the crisis in the water economy is primarily the extensive development of the economy of the country, which lasted for many years. In order to stabilize and improve the ecological conditions of the water sector and to develop the directions of crisis management, it is necessary to understand the reasons that has led to it. They are, first of all, the following: high resource and energy consumption of old technologies, which are 2-3 times higher than in the developed countries; high concentration of outdated industrial objects; the lack or insufficient power of purification facilities and the imperfection of purification technologies; lack of legal and economic mechanisms to stimulate the development of environmentally friendly technologies and environmental-protective systems.

\footnotetext{
5 Водний менеджмент в Україні: проблеми та інновації розвитку: [колективна монографія] /за ред. Л. Ф. Кожушко, В. А. Сташука, М. А. Хвесика, А. М. Рокочинського. Рівне, 2018. 638 с.
} 
The transition of Ukraine to sustainable development has to be preceded by the reform of economic policies and branches of the economy that have an environmental focus. The system of water economy complex and water resources management also needs to be reformed and switched into an integrated approach and basin principle, creation of institutions for collective management of water use, introduction of new economic instruments and levers through decentralization of management.

In the nearest perspective, the efficiency of the state's environmental policy should be based on the following basic principles: minimization of anthropogenic load and liquidation of its negative consequences, introduction of environmental protection, in particular water conservation, measures in the system of water use and diversion.

One of the priorities of the environmental policy of Ukraine is the harmonization of Ukrainian legislation with the EU one. For the realization of the Decree of the President of Ukraine «About the Program of Integration of Ukraine into the European Union», the Cabinet of Ministers adopted a number of measures directed at the gradual harmonization of Ukrainian legislation in the field of environment, natural and water resources and environmental safety with the EU directives ${ }^{6}$. The realization of the state policy of sustainable development of the water economy is based on the achievement of strategic goals, which include the reproduction and protection of water objects, the improvement of the technical and sanitary reliability of water economy systems, rational water use. The Law of Ukraine «On the National Program for the Development of Water Management» (dated 17.01.2002 No. 2988-III) provides for the following prospective priority measures: the realization of measures concerning the improvement of the ecological conditions of meliorative systems and bring the ecological and resource conditions of water objects to the requirements of basic standards that would guarantee the safety of life of the population and the achievement of the balance between the levels of anthropogenic influence on water objects and their recovery capacity. The achievement of these goals implies a targeted policy towards the main water users. In housing, the most important task is to take steps to achieve the efficient functioning of purification constructions. For that, it is necessary to limit the reception without local purification of industrial effluents, to build the constructions of additional purification of waste-waters, not to allow the overload in the work of purification constructions.

\footnotetext{
6 Указу Президента України «Про програму інтеграції України в Європейський Союз». Прийняття від 10.07.2015. Режим доступу: https://zakon.rada.gov.ua/laws/show/ n0001100-00.
} 
In agriculture, it is necessary to introduce a complex of agrotechnical measures and engineering technologies to reduce the income of pollutants, the water consumption of irrigated agriculture.

Realization of the planned measures requires improvement of the normative base of water use, increase of the quality of observations on the conditions of water objects (monitoring, state control in the field of water use, improvement of state water cadastre), implementation of flexible economic methods of water use regulation. Water economy problems, which have a complex character and which are impossible to be solved without state support and coordination of inter-sector communications, are solved through the development and implementation of state target programs. These include problems that are typical for the whole territory of Ukraine provision of the population with qualitative drinking water, prevention of the harmful effects of water, recovery of water quality in water objects and other regional water economy environmental problems.

Much attention should be paid to solving the problem of village water supply. The main task is to provide at least $50 \%$ of the villages with centralized water supply in combination with water diversion systems, and especially where the population uses imported water.

Due to the increasing of crisis water-ecological phenomena and the introduction of limits on energy consumption in agriculture, there is a need to improve and optimize irrigation regimes and norms. A method of saving water and reducing irrigation rates at the expense of the reduction of water losses for evaporation that is achieved by nocturnal irrigation, subsoil and drip irrigation, reduction of the total hydro module of irrigation crop rotation through the formation of rotations is prospective. The defining principles of water supply and water use in the transition to sustainable socioeconomic development of the state are:

- priority of the social sphere of water use, provision of the population with qualitative drinking water and in sufficient quantity;

- management of water economy and water protection activities by the basin principle;

- ecologically adapted, by the water factor, development of the economic potential of the regions on the basis of the assessment of the conditions of water resources and forecasting their changes;

- introduction of water-saving technologies in economic sectors;

- optimization of national and regional interests on the basis of greening of technologies of water uptake from water-resource sources;

- compliance with international law, cooperation in the field of use and protection of trans-boundary aquatic ecosystems; 
- reconstruction and maintenance of ecological safety of renewal and modernization of water economy and meliorative systems;

- formation of legal, economic and organizational principles of rational water use.

Considering that the water economy complex of Ukraine is characterized by the formed productive potential and limited capacities, the main role in the further development of water economy should belong to the processes of reconstruction, modernization of water economy systems, replacement of outdated technologies and systems of water supply and water purification with innovative technologies.

\section{Peculiarities of implementation of integrated approach and basin principle in water resources management of Ukraine}

For the last 25 years, the population of Ukraine and the production of goods and services have declined significantly, leading to a significant reduction in both water consumption (from $30 \mathrm{~km} 3$ in 1990 to $<9.7 \mathrm{~km} 3$ in 2015) and wastewater discharges by various sectors of the economy (from $18 \mathrm{~km} 3$ in the 1990 s to $5.3 \mathrm{~km} 3$ in 2015) ${ }^{7}$. However, a corresponding improvement in the quality of water resources is not observed, on the contrary, there are negative trends of increasing water scarcity due to the pollution and depletion of water resources, degradation of aquatic ecosystems and on the background of a negative effect of climate change. Problems with public access to water objects and safe drinking water are increasing. One of the key reasons of the current situation is the inefficient management system in the field of protection and recovery of water, rational use of water resources and development of water economy and land reclamation.

Despite the creation of basin administrations within the territorial structure of the State Agency for the past decade, the management is carried out at the level of administrative units: regions, districts or inter-regional or inter-district interaction of the objects of the water economy complex, without taking into account the basic natural factors of formation and interconnection of water (surface and underground) resources within the river basin - the water intake territory.

Agriculture of Ukraine directly generates 17\% of GDP, $20 \%$ of exports and more than $14 \%$ of work positions and is one of the most important points of growth of the national economy. The inefficient management of the state water economy complex and its under-funding for the purposes of tending, maintenance and re-equipment hinder the full utilization of

\footnotetext{
${ }^{7}$ Яцик А.В. Водогосподарська екологія: у 4 т., т.3. К.: Генеза, 2004. Кн. 5.496 с.
} 
agricultural potential of Ukraine. As of 2018, just about 510 thousand ha of agricultural lands are irrigated, which is $84 \%$ less than in 1990.

Much of the territory of Ukraine is located in the area of insufficient moisture. Global climate changes has led to a significant expansion of the territory with a lack of natural humidification. From 1990 to 2018, the area of arid and very arid zones in Ukraine increased by 8 million ha in comparison to the period of 1960-1990. Under these conditions, sustainable agriculture is impossible without irrigation.

The typical for the State Agency and its territorial bodies combination of functions in implementation of the state policy in the sphere of management, use, recovery of water resources and economic functions, such as meeting the needs of the population and sectors of the economy in water resources, conduction of the management of the objects of state property, ensuring the exploitation of state water economy objects and provision of the design, construction and reconstruction of the systems for protection against harmful effects of water, creates a base for the occurrence of conflicts of interests.

The parallel existence of two organizational structures (basin and administrative-territorial) increases the inefficiency of management and causes duplication and improper functioning, dispersion of limited resources (personnel, financial, material and technical and others), untimely response to the emergence of new management problems.

The structure and system of water management within river basins require the continuation of appropriate and proper organizational reform according to the basin principle, the introduction of the European governance model and the best world practices, and the system of management of the state water economy complex besides, in the part of providing with corresponding services, requires the introduction of marketbased foundations of the economic activity conduction.

The EU Water Framework Directive proposes a fundamentally new approach to the basin water management system ${ }^{8}$. The principle is that the main management unit is the water object pool. An integrated approach to water management enables balanced management and recovery of water resources, taking into account social, economic and environmental requirements and needs. The integrated approach coordinates the management of water resources in different sectors of the economy from local to international level. This approach involves incorporating more sophisticated water management system and more efficient institutional structure into the balanced water management process and legislative

\footnotetext{
${ }^{8}$ Директива 2000/60/СС Свропейського Парламенту і Ради «Про встановлення рамок діяльності Співтовариства в галузі водної політики» від 23 жовтня 2000 р. Режим доступу: http://zakon2.rada.gov.ua/laws/show/994_962
} 
framework, which is necessary for balanced management decisions. It is well known that the key principle of integrated water management is the basin principle. The National Target Program for the Development of Water Management and Environmental Improvement of the Dnipro River by 2021 in Ukraine provides for the implementation of a complex of measures concerning the introduction of the integrated water resources management system by the basin principle. Also, the Law of Ukraine «On the Fundamental Principles (Strategy) of the State Environmental Policy until 2020 », adopted in 2010, stipulates that the state administration system in the field of water protection needs urgent reform in the direction of transition to integrated water resources management by the basin principle 9 . The basin principle is defined as the complex integrated management of water resources within the river basin territory. The territory of the water basin may be the basin of one large river or, otherwise, include several basins of small rivers. Besides, the river basin territory can be located within one country as well as within several countries.

As the state of water resources depends directly on the quality of their management, environmental and water policy of the state, in 2016 the Law of Ukraine "On the Introduction into Some Legislative Acts of Ukraine on the Implementation of Integrated Approaches in Water Resources Management by the Basin Principle" was adopted ${ }^{10}$. This law has introduced into the existing legislation relevant concepts related to the basin principle of water resources management and additions, namely:

- the basin management principle - complex (integrated) water resources management;

- the river basin management plan - a document containing an analysis of the conditions and a complex of measures to achieve the objectives, set for each river basin district within the established time frame;

- the river basin district - the main unit of management for water use and protection and recovery of water resources, consisting of the river basin (adjacent river basins) and associated coastal and groundwater;

- the river basin (water intake) - a part of the earth's surface and a layer of soil, the runoff of water from which successively through connected reservoirs and streams is carried out into the sea, estuary or lake;

- the sub-basin - a part of the river basin, the runoff of water from which through the associated reservoirs and streams flows to the main river of the basin or water section downstream.

9 Закон України «Про основні засади (стратегію) державної екологічної політики до 2020 року». Прийняття від 21.12.2010. Режим доступу: https://zakon.rada.gov.ua/laws/show/ 2818-17.

10 Закон України «Про внесення до деяких законодавчих актів України щодо впровадження інтегрованих підходів в управлінні водними ресурсами за басейновим принципом» Прийняття від 04.10.2016 https://zakon.rada.gov.ua/laws/show/1641-19 
There are 9 river basin districts in Ukraine: the Dnipro River basin districts; the Dniester River Basin; the Danube River Basin; the Southern Buh River Basin; the Don River Basin; the Vistula River Basin; the river basin of Crimea; the Black Sea River Basin and the Azov River Basin District. Within the established river basin districts, the central executive body, which ensures the formation of state policy in the field of environmental protection, may allocate sub-basins. The boundaries of river basin districts, sub-basins and water economy plots are approved by the body of the central executive power, which ensures the formation of state policy in the field of environmental protection.

Water economy plots within river basin districts are allocated by taking into account the basin principle of management, administrative-territorial structure, physical and geographical conditions and economic activity, which ensures the formation of state policy in the field of environmental protection. The structure that manages the river basin is the Basin Council.

The Basin Council is a consulting and advisory body within the river basin territory, established under a body of the central executive power, which implements state policy in the field of water management, with the aim of ensuring the rational use and protection of waters and the recovery of water resources, integrated management of them ${ }^{11}$.

The planned basis of the basin management principle is a target program for the use, protection and recovery of water resources in the water intake basin, based on the normalization of anthropogenic load on them, requirements for water quality for the provision of the conservation of selfhealing ability and water regulation functions of rivers.

Interstate consulting bodies for integrated management of trans-boundary river basins are being formed to implement state-of-the-art computer systems for the support of management decisions under an integrated approach.

The guideline principles of the implementation of the basin management system in Ukraine should be:

- priority of ecological safety of water use and water consumption or priority of ecological policies of subjects of basin water use as the highest sector, corporate, local priorities and decisive factor of ecological improvement of the river basin, improvement of drinking water quality and sustainable development;

- basin co-ordination of environmental policies of basin management subjects and balance of their policies in the system of water use and water economy activity;

\footnotetext{
${ }^{11}$ Наказ Міністерства екології та природних ресурсів України від 26.01.2017 № 23 «Про затвердження Типового положення про басейнові ради». Режим доступу: https://zakon.rada.gov.ua/laws/show/z0231-17
} 
- self-sufficiency and self-compensation of the basin system of water use, water protection and recovery of water resources

- ecological and economic integrity of the system of water use, water protection and recovery of water resources;

- ensuring the interaction of basin management subjects on the basis of the program-based management method, integrated systematic approach and availability of the Main Basin Ecological and Economic Coordinator (Basin Council);

- standardization of the procedures and processes of basin management and normalization of the hierarchy of responsibility as guarantees of the efficiency of basin management and strengthening of responsibility for the quality of water resources and the conditions of water bodies of the basin;

- flexibility of organizational and legal structures and mechanisms in the basin management system, which can adequately adapt to the changing conditions of development (political, economic, legislative, productive and others);

- multivariant mechanisms of investment activity and financing of basin measures;

- the capability of the mechanism of stimulation of the efficiency and rational use of water and recovery of water resources;

- scientific substantiation of the management decisions and educational readiness for their implementation;

- complexity of the basin database and feedback efficiency (monitoring of the sustainable development of the basin).

The reform of the sphere of protection and recovery of water, rational use of water resources and development of water economy and land reclamation is being carried out, including reforming both the State Agency and enterprises, institutions and organizations belonging to the sphere of its management. The reform process will promote the coordinated development and management of water, land and other related resources within river basins, as well as achieving maximum social and environmental well-being on a fair basis, taking into account the interests of all water users in any part of the basin.

After the development and adoption of the new Law of Ukraine «About Water Users Consolidation», they will be created as non-profit public-law bodies and will be managed by their members to provide specialized irrigation and drainage services. A permanent consulting and advisory body of the Cabinet of Ministers of Ukraine - the National Council for the Protection, Recovery and Sustainable Management of Water Resources will be established to develop proposals and ensure coordination of actions of relevant associations of water users, bodies of local powers, enterprises, institutions and organizations involved in the use of natural resources in the river basins of Ukraine. 
In order to provide proper coordination of the activity of the bodies of state authorities in certain regions of the river basins of Ukraine, it is provided for the amendments to the current legislation of Ukraine to resubordinate the Basin Councils to the National Water Council. The main task of the National Water Council should be to implement integrated water basin management in accordance with the provisions of the EU Water Framework Directive and to implement methodological support for the creation of Basin Councils in the river basins and sub-basins.

With the financial support of the European Community, water management and flood protection projects are being developed and improved in the Dnipro, Tisza, Western Buh and Siverskyi Donets basins. In this regard, the State Agency of Ukraine actively cooperates with the Swedish Agency for International Development, within the framework of the TACIS program, NATO, the Danish Agency for Cooperation with Eastern Europe (DANCEE), the Swiss Confederation, Hungary, the USA, Poland and other countries. Further development of international cooperation will help to solve important problems directed to the improvement of the management, use and protection of water resources, as well as the approaching of the policies of Ukraine and the European Union in this field.

\section{CONCLUSIONS}

The existent nowadays system of water economy zoning and water resources management of Ukraine is based on two principles - hydrographic and administrative. The latter is even given the preference (many boundaries of water management plots are tied to the boundaries of administrative areas), because this principle was used to conduct public administration in the field of water use and protection and water resources recovery. The implementation of the basin management principle and the need to meet modern European requirements require the harmonization of the boundaries of water management areas with the boundaries of basins and sub-basins, which will be allocated within the territory of the country in accordance with the requirements of the EU Water Framework Directive.

\section{SUMMARY}

The article determines that Ukraine is one of the least well-supplied with water resources country among the European countries. Most natural water sources are scarce, and water resources of Ukraine are becoming a limiting factor in the development and distribution of productive forces. Due to the excessive anthropogenic load, disturbance of the conditions of river runoff formation and natural balance, which led to a decrease in the quality of water resources, the threatening ecological condition occurred in almost all river basins of Ukraine, and especially in the Dnipro basin - the main source of water supply in the country. More than $70 \%$ of the state's water supply is 
provided by the surface runoff of the Dnipro basin. Therefore, the issues of rational use of water resources, their recovery and protection are one of the main tasks of the state policy of Ukraine. Based on the analysis of the ecological conditions and hydro-chemical composition of the water of the basins of the major rivers of Ukraine, it was concluded that anthropogenic and technogenic load on aquatic ecosystems reached a critical limit due to extensive management and led to a significant reduction of ecological and sanitary expenditures and the depletion of water resources. As the state of water resources depends directly on the quality of their management, the environmental and water policy of the state, the article analyzes the existing legislative framework of Ukraine concerning the implementation of integrated approaches to water basin management. Principles that we consider to be the main guideline ones for the implementation of the basin management system in Ukraine are the following: priority of ecological safety, co-ordination of ecological policies of subjects of basin management, self-sufficiency and self-compensation of the basin system, ecological and economic integrity of the water system within the basin and process of standardization, scientific substantiation of management decisions, complexity of the basin database. It is proved that the implementation of the basin management principle requires taking into account the modern European requirements for harmonization of the boundaries of water areas with the borders of basins and sub-basins, which will be allocated in the territory of the country in accordance with the requirements of the EU Water Framework Directive.

\section{REFERENCES}

1. Постанова Верховної Ради України «Про Концепцію розвитку водного господарства України». Прийняття від 14.01.2000. Режим доступу: https://zakon.rada.gov.ua/laws/show/1390-14

2. Данилишин Б. М., Дорогунцов С. І., Міщенко В. С., Коваль Я. В., Новоторов О. С., Паламарчук М. М. Природно-ресурсний потенціал сталого розвитку України. К.: РВПС України, 1999. 716 с.

3. Дезірон О. В. Водокористування в Україні: сучасний стан та перспективи розвитку. Водне господарство Украӥни. К.: 2003, № 3-4. C. $4-8$.

4. Закон України «Загальнодержавна цільова програма розвитку водного господарства та екологічного оздоровлення p. Дніпро до 2021 року». Прийняття від 24.05.2012. Режим доступу: https://zakon.rada.gov.ua/laws/show/4836-17

5. Водний менеджмент в Україні: проблеми та інновації розвитку: [колективна монографія] /за ред. Л. Ф. Кожушко, В. А. Сташука, М. А. Хвесика, А. М. Рокочинського. Рівне, 2018. 638 с. 
6. Указу Президента України «Про програму інтеграції України в Європейський Союз». Прийняття від 10.07.2015. Режим доступу: https://zakon.rada.gov.ua/laws/show/n0001100-00.

7. Яцик А.В. Водогосподарська екологія: у 4 т., т.3. К.: Генеза, 2004. Кн. 5. 496 с.

8. Директива 2000/60/ЄС Європейського Парламенту і Ради «Про встановлення рамок діяльності Співтовариства в галузі водної політики» від 23 жовтня 2000 p. Режим доступу: http://zakon2.rada.gov.ua/laws/show/994_962

9. Закон України «Про основні засади (стратегію) державної екологічної політики до 2020 року». Прийняття від 21.12.2010. Режим доступу: https://zakon.rada.gov.ua/laws/show/2818-17.

10. Закон України «Про внесення до деяких законодавчих актів України щодо впровадження інтегрованих підходів в управлінні водними ресурсами за басейновим принципом» Прийняття від 04.10.2016 https://zakon.rada.gov.ua/laws/show/1641-19

11. Наказ Міністерства екології та природних ресурсів України від 26.01.2017 № 23 «Про затвердження Типового положення про басейнові ради». Режим доступу: https://zakon.rada.gov.ua/laws/show/ z0231-17

\section{Information about the author:} Stashuk V. A., Doctor of Engineering, Professor, Corresponding Member of NAAS, Institute of Irrigated Agriculture of the National Academy of Agrarian Sciences of Ukraine Kherson, Naddniprianske, 73483, Ukraine 